\title{
Anti-listerial inhibitory lactic acid bacteria isolated from commercial cold smoked salmon
}

\author{
Elisabetta Toméa,b, Paula Teixeira ${ }^{\mathrm{a}, *}$, Paul A. Gibbs ${ }^{\mathrm{a}, \mathrm{c}}$ \\ ${ }^{a}$ Escola Superior de Biotecnologia, Universidade Católica Portuguesa, R. Dr. António Bernardino de Almeida, 4200-072 Porto, Portugal \\ ${ }^{\mathrm{b}}$ Instituto de Ciencias y Tecnología de Alimentos. Escuela de Biología. Universidad Central de Venezuela. Apartado 47.097-Caracas 1041 A, Venezuela \\ ${ }^{\mathrm{c}}$ Leatherhead Food International, Surrey, UK
}

\begin{abstract}
The natural microflora of cold-smoked fish at the end of shelf-life are lactic acid bacteria (LAB). Some of these display a capacity to inhibit spoilage as well as several strains of pathogenic micro-organisms, e.g. Listeria monocytogenes which is isolated frequently from cold-smoked salmon (CSS).

Eight batches of sliced vacuum-packed CSS from Norway, Scotland and Spain were collected at retail. Packs were stored at $5{ }^{\circ} \mathrm{C}$ and examined for chemical and microbiological characteristics, at purchase date and at expiration date. $\mathrm{pH}$, water activity and salt content were similar to available data on lightly preserved fish products. There was a consistent pattern in the development of the microflora on CSS; the initial level of LAB was low on freshly produced CSS $\left(10^{2} \mathrm{cfu}^{-1}\right)$; however, storage in vacuum packaging at refrigeration temperature was elective for LAB. At the end of the stated shelf-life these micro-organisms, represented mainly by Lactobacillus spp., attained ca. $10^{7} \mathrm{cfu} \mathrm{g}^{-1}$ while Enterobacteriaceae counts were consistently lower $\left(10^{5} \mathrm{cfu}^{-1}\right)$, which indicates the ability of LAB to grow and compete with few carbohydrates available and in the presence of moderate salt concentrations. $L$. monocytogenes was not found in any sample.

Forty-one percent of LAB strains isolated exhibited inhibitory capacity against Listeria innocua, in a plate assay. A majority of the inhibitory effects were non-bacteriocinogenic, but nevertheless were very competitive cultures which may provide an additional hurdle for improved preservation by natural means.
\end{abstract}

Keywords: Cold smoked fish; Lactic acid bacteria; Salmon; Bacteriocins; Listeria; Preservation; Competitive bacteria

\section{Introduction}

The consumer acceptance of minimally processed refrigerated foods has been increasing during the past several years (Montville and Kaiser, 1993). However, the microbiological safety of these foods is of concern due to the possible presence of non-proteolytic strains of Clostridium botulinum able to grow at $4{ }^{\circ} \mathrm{C}$, and postprocessing contamination with other psychrotrophic

\footnotetext{
*Corresponding author. Tel.: + 351225580001 ; fax: +351225090351 .

E-mail address: paula@esb.ucp.pt (P. Teixeira).
}

pathogens, such as Listeria monocytogenes (Wessels et al., 2004).

L. monocytogenes may be found in cold-smoked salmon (CSS), typically in low numbers (Cortesi et al., 1997; Jørgensen and Huss, 1998), and it is possible that the lactic acid bacterial microflora developing during storage of CSS, may play an important role in controlling the growth of this pathogen. Inhibition results from the production of natural preservatives such as organic acids, hydrogen peroxide and diacetyl, and antimicrobials such as bacteriocins, as well as competition for, or depletion of, specific nutrients (see for example, Devlieghere et al., 2004; Buchanan and Bagi, 1997; Nilsson et al., 1999). 
The purpose of this study was to characterize the LAB microflora of sliced vacuum-packed CSS from different countries and manufacturers, and specifically to test the antagonistic activity of LAB isolated from those products, against $L$. innocua and $L$. monocytogenes. The nature of the inhibition was also investigated, by neutralizing the acidity of LAB culture supernatants and treatment with catalase and trypsin.

\section{Materials and methods}

Eight batches (each one consisting of $6 \times 100$-g packs) of sliced vacuum-packed, CSS, from Norway (P1-P4), Scotland (P5-P6) and Spain (P7-P8) were collected at retail. Packs were stored at $5{ }^{\circ} \mathrm{C}$ and examined for chemical and microbiological characteristics, at the purchase date $\left(T_{0}\right)$ and at the expiry date $\left(T_{1}\right)$, just 35 days after $T_{0}$. The dates of manufacture of products were not stated on the packs. The country of origin of the raw salmon was stated as Norway except for Scottish CSS (P5-P6) in which case the salmon was from Scotland. Declared ingredients included smoked salmon (Salmo salar), salt and sugar. Two of the four samples of CSS from Norway, denoted as P1 and P3, were made without sugar.

\section{Physico-chemical analyses}

Salt concentration was determined according AOAC (1995), method 937.09. The salt content was expressed as $\% \mathrm{NaCl}$ in water phase of muscle (Tomé et al., 1999).

Moisture contents of samples of CSS were evaluated according AOAC (1995), method 24.003.

Water Activity $\left(a_{\mathrm{W}}\right)$ was determined using a Rotronic Hygroskop DT Instrument (Rotronic AG, Zurich, Switzerland).

$p H$ was measured in smoked fish homogenates (1:1 mix of CSS and distilled water, stomached for $2 \mathrm{~min}$ ) with a micropH $2002 \mathrm{pH}$ meter (Crison, Barcelona, Spain).

\section{Microbiologic alanalyses}

At $T_{0}$ and at $T_{1}, 10 \mathrm{~g}$ of fillets were homogenized in $90 \mathrm{ml}$ of $1 / 4$ strength Ringer's solution (Lab M, Manchester, UK) for $2 \mathrm{~min}$ in a Stomacher $400 \mathrm{Lab}$ Blender (Seward Medical, London, UK). Serial decimal dilutions in $1 / 4$ strength Ringer's solution were prepared.

Total viable counts (TVC) were determined by spread-plating suitable dilutions on Long and Hammer's Medium, (L \& H; as modified by van Spreekens, 1974) $+1 \%$ w/v NaCl (Merck, Darmstadt, Germany), and plates were incubated aerobically at $25^{\circ} \mathrm{C}$ for 5 days.
Lactobacillus spp. were enumerated in pour plates of MRS (LAB M; De Man et al., 1960) agar medium, incubated aerobically $\left(25^{\circ} \mathrm{C}\right.$ for 3 days).

Total lactic acid bacteria (LAB) were enumerated by pour-plating in nitrite actidione polymyxin (NAP) agar, pH 6.7 (Davidson and Cronin, 1973). All colonies were counted as presumptive LAB after 5 days of anaerobic incubation at $25^{\circ} \mathrm{C}$.

Enterobacteriaceae were determined using overlaid plates of violet red bile glucose agar (VRBGA; Biokar Diagnostics, Beauvais, France). Plates were incubated at $37^{\circ} \mathrm{C}$ for $24 \mathrm{~h}$.

Detection of L. monocytogenes was performed following the ISO11290-1 protocol (ISO, 1996). All tubes were streaked onto PALCAM agar (Merck); incubated at $35^{\circ} \mathrm{C}, 48 \mathrm{~h}$. Typical colonies were streaked onto Tryptone Soy Yeast Extract agar (TSA-YE; Tryptone Soy Broth (Lab M) $+6 \mathrm{gl}^{-1}$ yeast extract (Lab M) $+12 \mathrm{~g} \mathrm{l}^{-1}$ agar (Lab M); incubated at $37^{\circ} \mathrm{C}$ for $24 \mathrm{~h}$ for further confirmation and identification by Gram staining, catalase activity, CAMP test with Staphylococcus aureus and Rhodococcus equi and also by mannitol, rhamnose and xylose fermentation.

Enumeration of $L$. monocytogenes was by the most probable number (MPN) technique. The values of the MPN for three tubes inoculated from each of three successive 10-fold dilutions were determined according to Harrigan and McCance (1986) MPN calculations.

Isolation and phenotypic characterizatio no fmicroorganisms

At $T_{0}$ and $T_{1}, 10 \%$ of colonies overall were picked randomly from NAP plates containing 10-100 colonies. Presumptive LAB were subcultured on NAP agar without selective agents or on all-purpose Tween (APT, Difco) agar, examined for purity and characterized using Gram stain, cytochrome oxidase, and catalase tests. Organisms that were Gram positive, cytochrome oxidase negative and catalase negative were stored in APT broth with glycerol $(30 \% \mathrm{v} / \mathrm{v})$ at $-80^{\circ} \mathrm{C}$.

\section{Anti-listerial activity}

Antimicrobial activity of the LAB isolates was investigated against L. innocua 2030c (Central Public Health Laboratory, Colindale, London), a tetracyclineresistant strain. Challenge studies with cold smoked fish have shown that L. innocua 2030c can be considered a suitable marker for replacing $L$. monocytogenes in experiments where anti-listerial properties of $\mathrm{LAB}$ strains are evaluated (Vaz-Velho et al., 2001). An overnight culture $\left(37^{\circ} \mathrm{C}\right)$ of L. innocua 2030c, was diluted in sterile APT broth to an OD (UNICAM 8620, Cambridge, England) between 0.2 and 0.3 (ca. $10^{6} \mathrm{cfu} \mathrm{m}^{-1}$ ) before use, and $200 \mu 1$ were spread on 
APT agar medium with a swab. Drops $(10 \mu \mathrm{l})$ of each LAB culture, previously grown in APT broth at $25^{\circ} \mathrm{C}$ for $48 \mathrm{~h}$, were then inoculated. Plates were incubated at $25^{\circ} \mathrm{C}$ for $48 \mathrm{~h}$. Any clear zones of inhibition around the LAB culture spot were measured.

From the above assay, LAB cultures showing defined inhibition zones, $>8 \mathrm{~mm}$ zone width, were selected. Zones of $<8 \mathrm{~mm}$ tended to disappear after $48 \mathrm{~h}$ incubation. Cell-free culture supernatants were spotted against L. innocua. Anti-listerial LAB supernatants were also tested against the producing organisms already stated and four different strains of L. monocytogenes previously isolated from smoked salmon or trout.

In order to determine the nature of the inhibition, the $\mathrm{pH}$ of cell-free supernatants was adjusted to 6.5 with $\mathrm{NaOH}(1 \mathrm{~N})$ and then treated with catalase (Sigma; $500 \mathrm{IU} \mathrm{m}^{-1}$ ) and trypsin (Sigma; $0.1 \mathrm{mg} \mathrm{ml}^{-1}$ ). Neutralized cell-free supernatant, neutralized cell-free supernatant treated with catalase and neutralized cell-free supernatant treated with catalase and trypsin, were spotted against the producing organisms and against $L$. innocua and L. monocytogenes.

Lactobacillus sakei CTC 494 (CTC, IRTA Meat Technology Centre Collection Monells, Spain) was used as an anti-listerial reference strain in this study.

\section{LAB identication}

Those cultures of which the cell-free supernatant showed anti-listerial properties were identified using the API $50 \mathrm{CH}$ kit (BioMerieux, Lyon, France) and analysed by APILAB PLUS software version 3.2.2.

\section{Statistical analyses}

One-way ANOVA and multiple range test were used to evaluate differences between means of $\mathrm{pH}$, salt, aw and microbiological counts, using the least significance difference (LSD) test at a significance level of $5 \%$. Calculations were carried out using Statgraphics Plus (Rockville, USA).

\section{Results}

\section{Chemical and physico-chemical characteristics}

Results of analyses of vacuum-packaged CSS are summarized in Table 1. The eight lots collected at retail from different producers were relatively homogeneous in their salt concentrations in the water phase, ranging between $4.12 \%$ and $4.99 \%$ with an average concentration of $4.50 \pm 0.28 \%$.

The $\mathrm{pH}$, initially with an average value equal to $5.99 \pm 0.10$, remained relatively unchanged during the
Table 1

Physical and chemical characteristics of refrigerated vacuum-packed CSS $(S$. salar $)$ from different producers, at purchase date $\left(T_{0}\right)$ and at the expiry date $\left(T_{1}\right)$

\begin{tabular}{lllll}
\hline Producer $^{\mathrm{A}}$ & $\mathrm{NaCl}(\%)^{\mathrm{B}}$ & $\mathrm{pH}$ & \multirow{2}{*}{$a_{\mathrm{W}}$} \\
\cline { 3 - 4 } & & $T_{0}$ & $T_{1}$ & \\
\hline P1 & $4.31^{\mathrm{a}}$ & $5.95^{\mathrm{a}}$ & $6.07^{\mathrm{a}}$ & $0.958^{\mathrm{bc}}$ \\
P2 & $4.75^{\mathrm{a}}$ & $6.25^{\mathrm{a}}$ & $6.22^{\mathrm{a}}$ & $0.938^{\mathrm{a}}$ \\
P3 & $4.99^{\mathrm{a}}$ & $5.94^{\mathrm{a}}$ & $5.93^{\mathrm{a}}$ & $0.938^{\mathrm{a}}$ \\
P4 & $4.28^{\mathrm{a}}$ & $5.97^{\mathrm{a}}$ & $5.91^{\mathrm{a}}$ & $0.955^{\mathrm{b}}$ \\
P5 & $4.55^{\mathrm{a}}$ & $5.97^{\mathrm{a}}$ & $5.90^{\mathrm{a}}$ & $0.951^{\mathrm{b}}$ \\
P6 & $4.12^{\mathrm{a}}$ & $5.98^{\mathrm{a}}$ & $5.92^{\mathrm{a}}$ & $0.962^{\mathrm{c}}$ \\
P7 & $4.48^{\mathrm{a}}$ & $5.93^{\mathrm{a}}$ & $6.21^{\mathrm{a}}$ & $0.951^{\mathrm{b}}$ \\
P8 & $4.52^{\mathrm{a}}$ & $5.97^{\mathrm{a}}$ & $5.93^{\mathrm{a}}$ & $0.953^{\mathrm{b}}$ \\
Average & $4.50^{\mathrm{a}}$ & $5.995^{\mathrm{a}}$ & $6.011^{\mathrm{a}}$ & 0.951 \\
SD & $0.28^{\mathrm{a}}$ & 0.104 & 0.136 & 0.009 \\
\hline
\end{tabular}

Means in the same column with the same letter are not significantly different $(P>0.05)$.

${ }^{\mathrm{A}}$ Six packages from each producer

${ }^{\mathrm{B}}$ Salt content in water phase

storage of all the samples, with an average value of $6.01 \pm 0.14$ at the end of the stated shelf-life.

Water activity $\left(a_{\mathrm{W}}\right)$ with an average value of $0.95 \pm 0.01$, had the lowest mean value in Norwegian smoked samples (0.94) and the highest (0.96) in one of the two Scottish samples.

\section{Microbiological status}

Results of microbiological analyses at the purchase date $\left(T_{0}\right)$ and at the expiry date $\left(T_{1}\right)$ are listed in Table 2.

The initial number of micro-organisms recovered on $\mathrm{L} \& \mathrm{H}$ medium ranged between $10^{2}$ and $10^{4} \mathrm{cfu}^{-1}$, with statistically significant differences $(P<0.05)$ between the two Scottish and the two Spanish producers.

During the storage period, TVC increased significantly, independently of the manufacturer, reaching values between $10^{5}$ and $10^{7} \mathrm{cfu} \mathrm{g}^{-1}$ at the expiration date of the product.

The initial counts of Lactobacillus spp. recovered on MRS agar were, in general, low $\left(10^{2}-10^{3} \mathrm{cfu} \mathrm{g}^{-1}\right)$ and became dominant under refrigerated storage, increasing to $10^{5}-10^{7} \mathrm{cfu} \mathrm{g}^{-1}$. Higher counts of these micro-organisms were found in samples P4, P5, P6, P7 and P8. The lowest counts, samples $\mathrm{P} 1$ and $\mathrm{P} 3$, were both from products manufactured without addition of sugar.

Initial total $\mathrm{LAB}$ counts ranged between $10^{2}$ and $10^{4} \mathrm{cfu}^{-1}$. Statistically significant differences between samples P6 and P8 were found between MRS and NAP counts at $T_{0}$. During vacuum-packed storage at $5{ }^{\circ} \mathrm{C}$, total $\mathrm{LAB}$ increased. Counts on MRS agar became equal to counts on NAP agar except for P3, indicating that Lactobacillus was generally the dominant genus. 
Table 2

Microbiological status of refrigerated vacuum-packed CSS at the purchase date $\left(\mathrm{T}_{0}\right)$ and after 5 weeks of refrigerated storage $\left(T_{1}\right)$.

\begin{tabular}{|c|c|c|c|c|c|c|c|c|c|c|}
\hline \multicolumn{11}{|c|}{ Microbial counts $\left(\log \mathrm{cfu} \mathrm{g}^{-1}\right)$} \\
\hline \multirow[t]{2}{*}{ Producer $^{\mathrm{A}}$} & \multicolumn{2}{|c|}{ TVC (L\&H) } & \multicolumn{2}{|c|}{ Lactobacillus spp. (MRS) } & \multicolumn{2}{|c|}{ Total LAB (APT) } & \multicolumn{2}{|c|}{ Enterobacteriacea (VRBG) } & \multicolumn{2}{|c|}{ L. monocytogenes (MNP) } \\
\hline & $T_{0}$ & $T_{1}$ & $T_{0}$ & $T_{1}$ & $T_{0}$ & $T_{1}$ & $T_{0}$ & $T_{1}$ & $T_{0}$ & $T_{1}$ \\
\hline P1 & $2.69^{\mathrm{a}}$ & $5.67^{\mathrm{d}}$ & $3.51^{\mathrm{ab}}$ & $5.44^{\mathrm{d}}$ & $3.22^{\mathrm{a}}$ & $5.74^{\mathrm{de}}$ & $3.58^{\mathrm{b}}$ & $5.02^{\mathrm{c}}$ & $<0.3$ & $<0.3$ \\
\hline $\mathrm{P} 2$ & $2.69^{\mathrm{a}}$ & $7.14^{\mathrm{fg}}$ & $2.06^{\mathrm{a}}$ & $6.52^{\mathrm{ef}}$ & $2.23^{\mathrm{a}}$ & $6.42^{\mathrm{e}}$ & $2.32^{\mathrm{a}}$ & $5.02^{\mathrm{c}}$ & $<0.3$ & $<0.3$ \\
\hline P3 & $3.01^{\mathrm{a}}$ & $6.13^{\mathrm{e}}$ & $2.79^{\mathrm{a}}$ & $5.45^{\mathrm{d}}$ & $3.28^{\mathrm{a}}$ & $5.81^{\mathrm{e}}$ & $3.04^{\mathrm{a}}$ & $5.14^{\mathrm{cd}}$ & $<0.3$ & $<0.3$ \\
\hline P4 & $2.75^{\mathrm{a}}$ & $7.41^{\mathrm{g}}$ & $2.00^{\mathrm{a}}$ & $7.22^{\mathrm{g}}$ & $2.00^{\mathrm{a}}$ & $7.55^{\mathrm{g}}$ & $2.00^{\mathrm{a}}$ & $5.44^{\mathrm{d}}$ & $<0.3$ & $<0.3$ \\
\hline P5 & $2.98^{\mathrm{a}}$ & $7.43^{\mathrm{g}}$ & $2.00^{\mathrm{a}}$ & $7.58^{\mathrm{g}}$ & $2.22^{\mathrm{a}}$ & $7.76^{\mathrm{gh}}$ & $2.46^{\mathrm{a}}$ & $5.00^{\mathrm{c}}$ & $<0.3$ & $<0.3$ \\
\hline P6 & $3.56^{\mathrm{b}}$ & $7.78^{\mathrm{h}}$ & $2.90^{\mathrm{a}}$ & $7.35^{\mathrm{g}}$ & $3.68^{\mathrm{b}}$ & $7.69^{\mathrm{gh}}$ & $2.60^{\mathrm{a}}$ & $6.32^{\mathrm{e}}$ & $<0.3$ & $<0.3$ \\
\hline P7 & $3.10^{\mathrm{a}}$ & $6.61^{\mathrm{f}}$ & $3.27^{\mathrm{ab}}$ & $7.29^{\mathrm{g}}$ & $4.16^{\mathrm{bc}}$ & $7.05^{\mathrm{fg}}$ & $2.00^{\mathrm{a}}$ & $3.74^{\mathrm{b}}$ & $<0.3$ & $<0.3$ \\
\hline P8 & $3.96^{\mathrm{b}}$ & $7.78^{\mathrm{h}}$ & $3.74^{\mathrm{b}}$ & $7.49^{\mathrm{g}}$ & $4.59^{\mathrm{c}}$ & $7.09^{\mathrm{fg}}$ & $2.41^{\mathrm{a}}$ & $4.08^{\mathrm{b}}$ & $<0.3$ & $<0.3$ \\
\hline
\end{tabular}

Means with the same letter are not significantly different $(P>0.05)$.

${ }^{\text {A }}$ Six packages from each producer

Counts of Enterobacteriaceae were initially low, ranging between $10^{2}$ and $10^{3} \mathrm{cfu} \mathrm{g}^{-1}$ at $T_{0}$, but increasing to ca. $10^{5} \mathrm{cfu}^{-1}$ after 5 weeks of vacuum storage, except for sample P6 and P7, P8 in which slightly higher and lower counts were recorded, respectively.

L. monocytogenes was not found in any sample.

\section{Anti-listerial activity and LAB identication}

The anti-listerial activity of 299 presumptive LAB picked from NAP plates, at the purchase date $\left(T_{0}\right)$ and 331 strains of LAB picked after 5 weeks of refrigerated storage in vacuo $\left(T_{1}\right)$ was evaluated. Inhibition zones against $L$. innосиа $\geqslant 8 \mathrm{~mm}$ were observed for 261 $(41.4 \%)$ isolates. Fig. 1 shows the percentage of inhibitory organisms (as cultures) isolated at $T_{0}$ and $T_{1}$ from products from each manufacturer. Most of the inhibitory isolates, except notably in $\mathrm{P}_{3}$ and $\mathrm{P}_{4}$, were isolated at $T_{0}$.

From the cultures with antagonistic properties, only six cell-free supernatants showed inhibitory activity against L. innocua 2030 c.

All six live culture isolates and their cell-free supernatants, were able to inhibit $L$. monocytogenes in an in vitro assay performed at $25^{\circ} \mathrm{C}$ (Table 3), although the inhibitory activity was greater with live cells than with cell-free supernatants (data not shown). Anti-listerial activity was lost in two cell-free supernatants after adjusting their $\mathrm{pH}$ to 6.5 , which suggests that their inhibitory activity was due to organic acids.

Another two cell-free supernatants were inactivated by catalase. Anti-listerial activity by proteolytic compounds was found in two strains which make them promising candidates for biopreservation of CSS stored at $5^{\circ} \mathrm{C}$.

According to the carbohydrate fermentation patterns, all of these inhibitory strains belong to the genus Lactobacillus or Lactococcus. The two strains considered

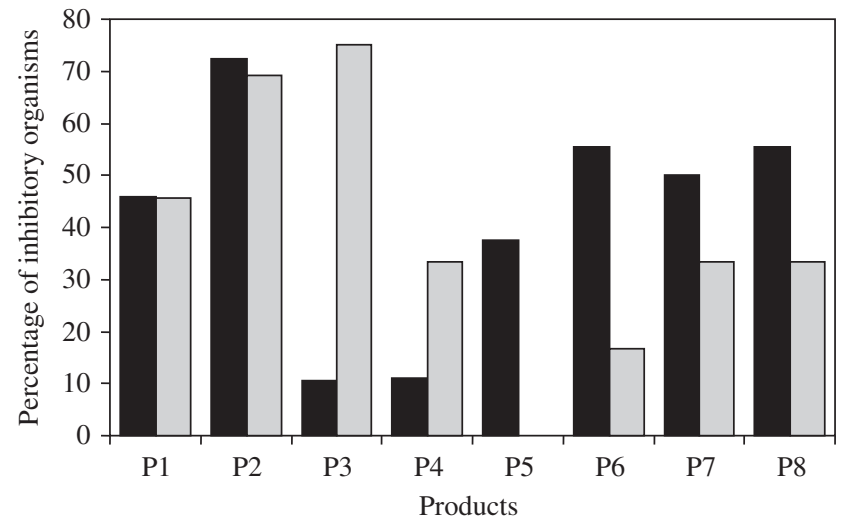

Fig. 1. Percentages of anti-listerial LAB cultures obtained from cold smoked salmon fillets produced by different manufacturers (P1-P8), during refrigerated storage $\left(5^{\circ} \mathrm{C}\right) . T_{0} \boldsymbol{\square} ; T_{1} \square$.

as bacteriocin-producing LAB, were Gram-positive cocci, and successfully identified as Lactococcus lactis $(P=99.9 \%)$. The others strains are short, Grampositive rods, two of them (acid-producing LAB) identified as Lactobacillus plantarum and the last two strains (hydrogen peroxide-producing LAB) as Lactobacillus brevis ( $P=99.9 \%$, respectively). These microorganisms were previously isolated from CSS and other fish products (Antara et al., 2002; González-Rodríguez et al., 2002; Sharp and Pettipher, 1983).

No auto-inhibition was observed.

\section{Discussion}

Chemical and physico-chemical characteristics

In all samples salt-on-water concentrations were higher than the minimum guidelines for vacuum- 
Table 3

Inhibitory activity $(25 \mathrm{oC})$ of lactic acid bacteria against $L$. innocua $2030 \mathrm{c}$ and $L$. monocytogenes determined by a spot assay on APT agar

\begin{tabular}{|c|c|c|c|c|c|}
\hline \multirow[t]{2}{*}{ Producer strain } & \multicolumn{5}{|c|}{ L. monocytogenes strains and L. innocua (2030c) } \\
\hline & $\begin{array}{l}\text { Live-cell } \\
\text { supernatant }\end{array}$ & $\begin{array}{l}\text { Cell-free } \\
\text { supernatant }\end{array}$ & $\begin{array}{l}\text { Cell-free } \\
\text { supernatant }{ }^{\mathrm{a}}\end{array}$ & $\begin{array}{l}\text { Cell-free } \\
\text { supernatant }{ }^{\mathrm{a}} \text { treated } \\
\text { with catalase }^{\mathrm{b}}\end{array}$ & $\begin{array}{l}\text { Cell-free supernatant } \mathrm{t}^{\mathrm{a}} \\
\text { treated with catalase }{ }^{\mathrm{b}} \& \\
\text { trypsin }^{\mathrm{c}}\end{array}$ \\
\hline E1 & + & + & + & - & - \\
\hline E2 & + & + & - & - & - \\
\hline E3 & + & + & + & - & - \\
\hline E4 & + & + & - & - & - \\
\hline E5 & + & + & + & + & - \\
\hline E6 & + & + & + & + & - \\
\hline L. sakei CTC 494 & + & + & + & + & - \\
\hline
\end{tabular}

${ }^{\mathrm{a}}$ Adjusted to $\mathrm{pH} 6.5$.

b $500 \mathrm{IU} \mathrm{ml}^{-1}$.

${ }^{\mathrm{c}} 0.1 \mathrm{mg} \mathrm{ml}^{-1}$; + inhibition zone; - no inhibition zone.

packaged cold-smoked fish processed without nitrites $(3.5 \%)$ (ACMSF, 1992).

The $\mathrm{pH}$ remained relatively unchanged during the storage of all the samples, reflecting low sugar contents and a strong buffering effect of fish muscle. Although there were no statistically significant differences $(P>0.05)$ in mean $\mathrm{pH}$ values among the samples, $\mathrm{pH}$ values close to $\mathrm{pH} 5.9$ were observed in most of the samples with higher lactobacilli counts (P4, P5, P6 and P8). Leroi et al. (1998) have shown that, among nine bacterial groups currently identified in CSS, Lactobacillus was the only genus which was able to acidify the products to these values.

\section{Microbiological status}

According to the samples analysed there was not a large variation in the microbial quality of smoked salmon offered on the Portuguese market.

Since the production date of these products was unknown (because they were acquired in the supermarket), the different storage temperatures to which the products were exposed before the purchase date, could explain at least in part, the variations in the quantitative microbiological composition found among them. Published data on the microbial contamination of CSS indicated that it is highly dependent on the storage temperature. According to Sirkorski (2002), the bacterial load on vacuum-packed CSS stored 4-7 days at $12^{\circ} \mathrm{C}$, may be about $2.5 \log$ cycles higher than at $6^{\circ} \mathrm{C}$. Furthermore, to control the microbiological quality of the final product, the initial contamination of the fish must be assessed because it could represent a risk of bacterial food poisoning caused by fish smoked in mild conditions $\left(<30^{\circ} \mathrm{C}\right)$.

The ability of Lactobacillus spp. to grow and compete, with only a low level of carbohydrates available and in the presence of moderate salt concentrations, is noteworthy. However, as shown in Table 2, the presence of sugar enhances the growth of lactobacilli, resulting from the fermentative nature of these micro-organisms. Previous studies (Leroi et al., 2001; Connil et al., 2002; Emborg et al., 2002) have demonstrated that LAB are potential spoilage organisms associated with higher total volatile basic nitrogen (TVBN) concentrations in CSS, reducing the shelf-life of this product.

According to Leroi et al. $(1998,2000)$, the carnobacteria count can be estimated by the difference between NAP and MRS counts; in $T_{0}$ samples P6 and P8, a proportion of the LAB probably belonged to the Carnobacterium genus. In $T_{1}$ samples, only P3 presented a difference in total LAB and MRS counts, suggesting that carnobacteria were a significant proportion of the LAB microflora developed in this sample. It is interesting to note that P3 was made without sugar.

Development of Enterobacteriacea seems to be correlated with a low sodium chloride concentration and higher $a_{\mathrm{w}}$, e.g. in P6 with a low salt a $4 \log$ increase, in P3 with highest sodium chloride concentration a $2 \mathrm{log}$ increase in Enterobacteriaceae counts.

The Enterobacteriaceae counts always remained 1-3 logs lower than TVC, indicating that they were not the dominant flora in any of these products. According to Leroi et al. (1999), the shelf life of smoked salmon is closely linked to the initial Enterobacteriaceae count; the higher the initial total count on VRBG agar, the shorter the shelf life.

L. monocytogenes was not found in any sample. The absence of $L$. monocytogenes in these samples of vacuum-packed fish, with an average salt concentration in water phase of $4.50 \%$, which would suppress the growth of $C$. botulinum in these products, could indicate good manufacturing practice and appropriate storage. 
The percentage of inhibitory cultures isolated at $T_{0}$ and $T_{1}$ shows a large variation between them, including between producers in the same country (Fig. 1).

These results indicate large differences in the compositions of the LAB between CSS samples, probably as a result of the different processing and hygiene conditions between manufacturers. As can be seen in Fig. 1, isolates from $T_{0}$ showed the greatest percentages of inhibitory strains in most of the samples. The greater percentages of inhibitory LAB on freshly produced cold-smoked fish could protect the product to a considerable degree against some pathogenic micro-organisms like L. monocytogenes, in which case, counts of this pathogen could be maintained at a low level during the storage.

The antagonistic activity by live cells was only observed in the corresponding filter supernatants of six isolates. These results suggest that the antagonistic mechanism of most of the isolates could be due to competition for or depletion of specific nutrients as has been suggested by Nilsson et al. (2005).

Inhibitory activity against $L$. innocua and strains of $L$. monocytogenes was lost in two cell-free supernatants when the $\mathrm{pH}$ was neutralized. Similar antimicrobial results to those reported here, were obtained by Aslim et al. (2005) when testing 19 cell-free supernatants of LAB isolated from Turkish dairy products. Among the Lactobacillus spp. cultures assayed, it was observed that inhibitory activity against strains of $L$. monocytogenes and $S$. aureus was lost in 15 cell-free supernatants, including $L$. plantarum culture-free supernatants, when the $\mathrm{pH}$ was neutralized.

Production of lactic acid, the major metabolite of $\mathrm{LAB}$, is responsible for the associated decrease in $\mathrm{pH}$, which may be sufficient to antagonize many microorganisms. The undissociated acid can cause the collapse of the electrochemical proton gradient of susceptible bacteria, leading to bacteriostasis and eventual death (Soomro et al., 2002).

Another two inhibitory cell-free supernatants were inactivated by catalase. Peroxide-producing LAB were identified as Lactobacillus brevis. Hydrogen peroxide is produced by a large number of LAB lacking the enzyme catalase - in particular by Lactobacillus spp.-and inhibits other micro-organisms such as Staphylococcus aureus and Listeria spp. The potential of $\mathrm{H}_{2} \mathrm{O}_{2}$ produced by LAB for food preservation, may be limited by the oxidizing nature of the molecule, and free radicals produced may have profound effects on the sensory quality, causing rancidity of fats and oils and discoloration reactions (Devlieghere et al., 2004). The production of acids and hydrogen peroxide by LAB and inhibitory properties have been registered by several authors (Juvnen et al., 1992; Tharrington and Sorrelis, 1992; Ocando et al., 1993; Guerra et al., 2001).
Anti-listerial activity by peptides or proteins was found in two strains identified as Lact. lactis, which make them promising candidates for biopreservation of cold-smoked salmon stored at $5{ }^{\circ} \mathrm{C}$. Several bacteriocins produced by Lactococcus lactis, other than nisin, have been identified: Lacticin 481, Lactococcin A, Lactococcin B and Lactococcin M (O'Sullivan et al., 2002). The first one belongs to Class I encompassing the small, post-translationally modified, broad host range lantibiotics, of which nisin is the best-known example, and the last three belong to Class II which includes the small, heat-stable unmodified peptides (Cleveland et al., 2001).

In conclusion, although the nature of most of the inhibitions was unknown, the presence in vacuumpacked CSS of a high proportion of inhibitory LAB, at high cell densities, may provide an additional hurdle for improved preservation by natural means.

\section{Acknowledgements}

Financial support to author Tomé was provided by a Ph.D. fellowship issued by Consejo de Desarrollo Científico y Humanístico de la Universidad Central de Venezuela.

\section{References}

Advisory Committee on the Microbiological Safety of Foods (ACMSF), 1992. Report on Vacuum Packaging and Associated Processes. Her Majesty's Stationery Office, London, UK.

Antara, N., Sujaya, I., Yokota, A., Asano, K., Aryanta, W.R., Tomita, F., 2002. World Journal of Microbiology and Biotechnology 18 (3), 255-262.

AOAC, 1995. Official Methods of Analysis, 15th ed. Association of Official Analytical Chemists, Washington DC, USA.

Aslim, B., Yuksekdag, Z., Sarikaya, E., Beyatli, Y., 2005. Determination of the bacteriocin-like substances produced by some lactic acid bacteria isolated from Turkish dairy products. Lebensm-Wiss. U.Technol., in press.

Buchanan, R., Bagi, L., 1997. Microbial Competition: Effect of culture conditions on the suppression of Listeria monocytogenes Scott A by Carnobacterium piscicola. J. Food Protect. 60, 254-261.

Cleveland, J., Montville, T., Nes, I., Chikindas, M., 2001. Bacteriocins: safe, natural antimicrobials for food preservation. Int. J. Food Microbiol. 71, 1-20.

Connil, N., Plissoneau, L., Onno, B., Pilet, M., Prévost, H., Dousset, X., 2002. Growth of Carnobacterium divergens V41 and Production of Biogenic amines and divercin V41 in sterile cold-smoked salmon extract at varying temperatures, $\mathrm{NaCl}$ levels, and glucose concentrations. J. Food Protect. 65 (2), 333-338.

Cortesi, M., Santoro, A., Murru, N., Pepe, T., 1997. Distribution behaviour of Listeria monocytogenes in three lots of naturally contaminated vacuum-packed salmon stored at 2 and $10^{\circ} \mathrm{C}$. Int. J. Food Microbiol. 37, 209-214.

Davidson, C., Cronin, F., 1973. Medium for the selective enumeration of lactic acid bacteria from foods. Appl. Microbiol. 26 (3), 439-440.

De Man, J.D., Rogosa, M., Sharpe, M.E., 1960. A medium for the cultivation of lactobacilli. J. Appl. Bact. 23, 130-135. 
Devlieghere, F., Vermeiren, L., Debevere, J., 2004. New preservation technologies: possibilities and limitations. Rev. Int. Dairy J. 14, $273-285$.

Emborg, J., Laursen, B., Rathjen, T., Dalgaard, P., 2002. Microbial spoilage and formation of biogenic amines in fresh and thawed modified atmosphere-packed salmon (Salmo salar) at $2{ }^{\circ} \mathrm{C}$. J. Appl. Microbiol. 92, 790-799.

González-Rodríguez, M., Sanz, J., Santos, J., Otero, A., García López, M.L., 2002. Numbers and types of microorganisms in vacuumpacked cold-smoked fresh water fish at the retail level. Int. J. Food Microbiol. 36, 1-29.

Guerra, M., Fernando, M., Bernardo, A., 2001. Characterization of the inhibitors effects of $L$. monocytogenes Scott A, produced by ripening microflora of Alentejo's traditional cheeses. Rev. portuguesa Ciencias Veterinarias 96 (538), 65-69.

Harrigan, W., McCance, M., 1986. En: Academia (Ed), Métodos de laboratorio en Microbiología de Alimentos y productos lácteos. León, España, pp. 361-366.

International Organization for Standarization, ISO 11290-1, 1996. Microbiology of food and animal feeding stuffs-Horizontal method for the detection and enumeration of Listeria monocytogenes-Part 1: Detection method.

Jørgensen, V., Huss, H., 1998. Prevalence and growth of Listeria monocytogenes in naturally contaminated seafood. Int. J. Food Microbiol. 42, 127-131.

Juvnen, B., Schned, F., Lindner, P., 1992. Antagonistic compounds produced by a chicken intestinal strain of Lactobacillus acidophilus. J. Food Protect. 55, 157-161.

Leroi, F., Joffraud, J., Chevalier, F., Cardinal, M., 1998. Study of the microbial ecology of cold-smoked salmon during storage at $8{ }^{\circ} \mathrm{C}$. Int. J. Food Microbiol. 39, 111-121.

Leroi, F., Joffraud, J., Stohr, V., Roy, C., Cardinal, M., Berdagué, J., 1999. Characterization of the spoilage micro-flora of refrigerated cold-smoked salmon. In: S.A. Georgakis, Thessaloniki, Greece, Proceedings of the 29th WEFTA Meeting, 10-14 October, Thessaloniki, Greece, pp. 116-123.

Leroi, F., Joffraud, J., Chevalier, F., 2000. Effect of salt and smoke on the microbiological quality of cold-smoked salmon during storage at $5^{\circ} \mathrm{C}$ as estimated by a factorial design method. J. Food Protect. 63 (4), 502-508.

Leroi, F., Joffraud, J., Chevalier, F., Cardinal, M., 2001. Research of quality indices for cold-smoked salmon using a stepwise multiple regression of microbiological counts and physico-chemical parameters. J. Appl. Microbiol. 90, 578-587.
Montville, T., Kaiser, J., 1993. Antimicrobial proteins: classification, nomenclature, diversity and relationship to bacteriocins. In: Hoover, D.G., Steenson, L.R. (Eds.), Bacteriocins of Lactic Acid Bacteria. Academic Press, New York, pp. 1-22.

Nilsson, L., Gram, L., Huss, H., 1999. Growth control of Listeria monocytogenes on cold-smoked salmon using a competitive lactic acid bacteria flora. J. Food Protect. 62, 336-342.

Nilsson, L., Hansen, T., Garrido, P., Buchrieser, C., Glaser, P., Knochel, S., Gram, L., Gravesen, A., 2005. Growth inhibition of Listeria monocytogenes by a non bacteriocinogenic Carnobacterium piscicola. J. Appl. Microbiol. 98, 172-183.

Ocando, A., Granados, A., Lasanta, Y., Gutierrez, B., Cabrera, L., 1993. Organic acids of low molecular weight produced by lactobacilli and enterococci isolate from Palmita type Venezuelan cheeses. Food Microbiol. 10, 1-7.

O’ Sullivan, L., Morgan, S., Ross, R., Hill, C., 2002. Elevated enzyme release from Lactococcal Starter Cultures on exposure to the Lantibiotic Lacticin 481, produced by Lactoccocus lactis DPC 5552. J. Dairy Sci. 85, 2130-2140.

Sharp, M., Pettipher, G., 1983. Food spoilage by lactic acid bacteria. Econ. Microbiol. 8, 199-223.

Sirkorski, Z., 2002. The quality and shelf life of smoked fish. J. Food Nutr. Sci. 44, 5-13

Soomro, A., Masud, T., Anward, K., 2002. Role of Lactic Acid Bacteria (LAB) in food preservation and human health - a review. Pak. J. Nutr. 1 (1), 20-24.

Tharrington, G., Sorrelis, K., 1992. Inhibition of Listeria monocytogenes by milk culture filtrates from Lactobacillus delbrueckii subsp. lactis. J. Food Protect. 55, 542-544.

Tomé, E., Matsunaga, Y., Kodaira, M., 1999. Effect of processing conditions, lipids contain and the freshness on acceptability of smoked catfish. Food Sci. Technol. Int. 5 (2), 167-175.

van Spreekens, K., 1974. The suitability of a modification of Long and Hammer's medium for the enumeration of more fastidious bacteria from fresh fishery products. Arch. Lebensmit. Hyg. 25, 213-219.

Vaz-Velho, M., Fonseca, F., Silva, M., Gibbs, P., 2001. Is Listeria innocua 2030c, a tetracycline resistant strain, a suitable indicator for replacing $L$. monocytogenes in challenge studies with coldsmoked fish? Food Control 12, 361-364.

Wessels, S., Axelsson, L., Hansen, E., Vuyst, L., Laulund, S., Lähteenmäki, L., Lindgren, S., Mollet, B., Salminen, S., Wright, A., 2004. The lactic acid bacteria, the food chain, and their regulation. Trends Food Sci. Technol. 15, 498-505. 